\title{
Overwintering by the Boll Weevil (Coleoptera: Curculionidae) in Conservation Reserve Program Grasses on the Texas High Plains
}

\author{
STAN C. CARROLL, DON R. RUMMEL, AND EDUARDO SEGARRA
}

Texas A\&M University Research and Extension Center, Lubbock, TX 79401

\begin{abstract}
J. Econ Entomol. 86(2): 382-393 (1993)
ABSTRACT Scarcity of suitable overwintering habitat is a major obstacle to the establishment of the boll weevil, Anthonomus grandis grandis Boheman, in cotton-producing counties of the Texas High Plains (THP). After introduction of the Conservation Reserve Program (CRP) in 1985, a 3-yr study was conducted to investigate the ovenvintering potential of the boll weevil in two CRP grass habitats on the THP. Overwintering 5urvival of the boll weevil in leaf litter of sand shinnery oak, Quercus havardii (Rydberg), in the Texas Rolling Plains (TRP) served as a comparison. CAP grasses provide marginal overwintering habilat when compared with sand shinnery oak leaf litter. For a given level of winter severity, total winter survival and effective emergence (emergence after approximately 15 June in the study area) were consistently lower in the CRP grasses than in sand shinnery oak leaf litter. Even with lower survival rates in THP grasses, economically damaging boll weevil infestations could follow mild winters if large diapausing populations develop in the fall. Pheromone traps located in CRP pastures on the THP indicated a relatively low level of overwintered boll weevil emergence during all three study years.
\end{abstract}

KEY WORDS Anthonomus grandis grandis, diapause, habitat

THE OBJECTIVE of this study was to determine if Conservation Reserve Program (CRP) grasses increased the probability of developing a resident boll weevil, Anthonomus grandis grandis Boheman, population on the Texas High Plains (THP). Previous observations have shown that the boll weevil is capable of overwintering on the THP if suitable overwintering habitats are available (Adkisson et al. 1965, Bottrell et al. 1972a). Brown \& Phillips (1989) indicated that weeping lovegrass, Erogrostis curvula (Schrader), in the neighboring Texas Rolling Plains (TRP) provided a very favorable overwintering habitat and they observed boll weevil survival rates that were comparable to those in sand shinnery oak, Quercus havardii (Rydberg), leaf litter. However, the winters were relatively mild during their 2-yr study.

The THP rests at a higher elevation than the TRP, and the geological formation separating the two regions is referred to as the Caprock escarpment (Fig. 1). Annual row crops dominate the cotton-producing counties of the southern THP, but the TRP has both row crops and rangeland. The growing season is shorter on the THP, and winters tend to be more severe than those experienced in the TRP. THP cotton producers annually harvest $=1.2$ million ha (three million acres) of cotton, which accounts for roughly $50 \%$ of the total cotton production in Texas, or $18-20 \%$ of the U.S. production. Although the boll weevi] has greatly expanded its range since its introduction into the United States in the late $1800 \mathrm{~s}$, it has not become established in the THP.

Each fall boll weevils migrate westward onto the THP from cotton-producing areas of the nearby TRP. Two major factors that have prevented permanent boll weevil colonization on the THP are the annual suppression of boll weevil populations by the Texas High Plains Boll Weevil Diapause Control Program and the scarcity of favorable overwintering habitat (Rummel et al. 1975). Rummel et al. (1975) noted, however, that favorable overwintering habitats exist in the southern and western counties of the THP. As a result of the CRP, over 400,000 ha (one million acres) of grasses were recently established in the cotton-producing counties of the THP. These CRP fields were previously planted to row crops that did not produce sufficient plantresidue accumulations to provide adequate boll weevil overwintering protection (Rummel et al. 1975). On the THP, numerous grass types are being used in the CRP. Bunch-type grasses, such as weeping lovegrass, produce a large amount of plant residue and thus have the greatest potential of providing adequate overwintering protection for the boll weevil. 


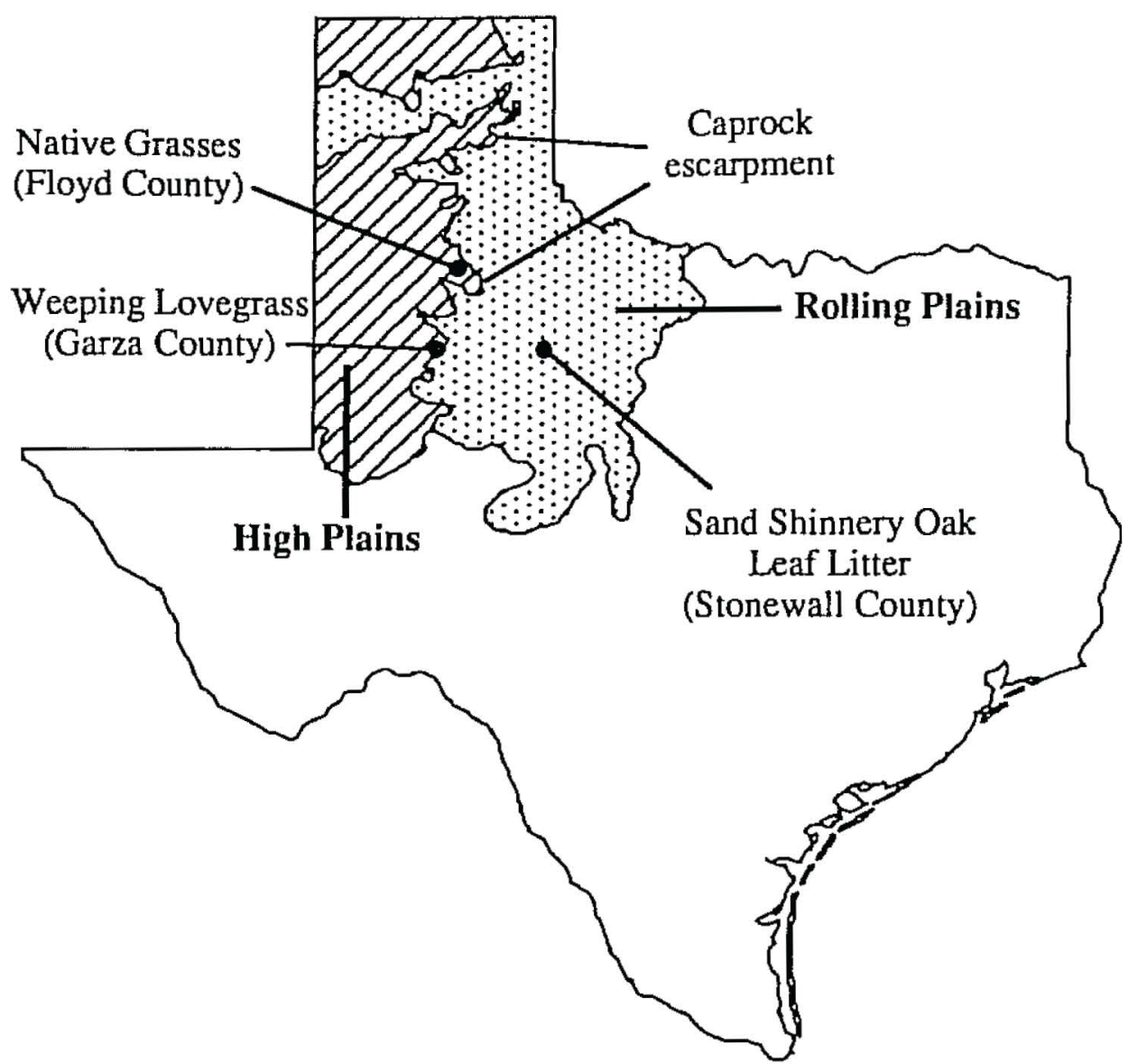

Fig. 1. Boll weevil averwintering study sites located in CRP grass pastures on the THP and in sand shinnery oak leaf litter in the TRP, 1987-1990.

This study investigated the overwintering survival of boll weevils caged on several selected types of CRP grasses on the THP. For comparison, weevils from the same population were caged on sand shinnery oak leaflitter in the TRP.

\section{Materials and Methods}

Relevant Texas vegetative regions (Gould 1962) utilized in the study and locations of the three study sites are shown in Fig. 1. The first CRP grass site was an established weeping lovegrass field located on the THP in western Garza County. A second CRP grass pasture consisting of four types of native grasses was selected near Dougherty in eastern Floyd County on the THP. The grass mixture consisted of sideoats grama, Bouteloua curtipendula (Michx.) Torr.; blue grama, Bouteloua glacilis (H.B.K.) Lag. ex Steud.; buffalograss, Buchloe dactyloides (Nutt.) Engelm.; and green sprangletop, Leptochloa dubia (H.B.K.) Nees. The third site was in Stonewall County in the neighboring TRP. The selected overwintering habitat at this site was sand shinnery oak leaf litter, $Q$. havardii, the prime boll weevil overwintering habitat in the TRP region (Rummel \& Adkisson 1970, Bottrell et al. 1972b). Sand shinnery oak tends to hybridize, resulting in a great diversity of plant height and canopy cover within a single pasture. A thicket, or motte, of relative tall sand shinnery oak as described by Slosser et al. (1984) was selected for use in this study.

Overwintering Cage Studies. Test bol] weevils were reared from infested squares collected from fields of cotton during the late summer and fall. The infested cotton fields utilized for collections were located in Kent, Knox, and Tom Green counties of the TRP. Because of the numerous cotton varieties used across the TRP, variety records were not maintained on the fields utilized for infested square collections.

Adult boll weevils emerging from infested squares during a given I-wk interval were caged together to form a cohort. The rearing room was programmed to maintain a temperature of 22$27^{\circ} \mathrm{C}$ and artificial lighting corresponding to the natural photoperiod. Each cohort was fed fresh 
cotton squares and small bolls daily for $=3 w k$. After completion of the feeding period, each cohort was divided for release into the selected overwintering habitats. With the exception of the eighth cohort of 1988-1989, each cohort was further divided at each study site so that known numbers of boll weevils could be released into two to four cone-shaped screen-wire overwintering cages ( $77 \mathrm{~cm}$ high by $77 \mathrm{~cm}$ base) placed in the habitats. Cages were positioned within the habitats so that individual cages were at least $1 \mathrm{~m}$ apart. The native grass site on the THP was not studied in 1987-1988. A combined total of 24, 45, and 32 overwintering cages was utilized in the overwintering studies of 1987-1988, 1988-1989, and 1989-1990, respectively. Over the $3 \mathrm{yr}$, the total number of adults released per cage per year ranged from 34 to 575 with an average of $247 \pm$ 153.

Several cohorts were released at intervals throughout the falls of 1987,1988 , and 1989 so that the range of times the caged population entered overwintering habitat would be representative of the range of times the native population entered overwintering habitat in each area. In the third study year, the shinnery oak habitat site was also utilized in another study. As a result, four cohorts were released in the sand shinnery oak habitat (15 September and 2, 12, and 27 October) and two other cohorts were divided and placed in the two grass habitats on 22 September and 20 October.

To measure overwintering potential accurately, the diapause status of the boll weevil population was determined. Immediately before release of each cohort, $=25$ weevils were dissected to determine the diapause status of that particular cohort (Brazzel \& Newsom 1959).

Plastic collection containers taken from pheromone traps (Hercon Scout, Hercon Laboratories Corp., York, PA) were affixed to the top of the cages to collect emerging boll weevils. Weekly inspections of cages throughout the spring and summer allowed us to calculate the overwintering survival rate and emergence pattern for boll weevils caged in each type of overwintering habitat.

Computerized dataloggers located at each of the study sites provided hourly weather data including ambient temperature at $2 \mathrm{~m}$ above the soil surface, relative humidity, wind speed, solar radiation, and temperature readings at different depths in the overwintering habitat both inside and outside of one emergence cage at each study site. Temperatures near the actual site of overwintering were obtained by placing temperature probes $=5 \mathrm{~cm}$ beneath the surface of litter in the sand shinnery oak leaf habitat and at the soil surface inside the crown area of the two grass habitats. The detailed weather data allowed us to determine environmental differences among the three study sites and to determine differences in the insulating properties of the selected overwintering habitats. An equipment failure at the Garza County study site (weeping lovegrass habitat) resulted in an incomplete weather data summary for this location during the winter of $1989-$ 1990.

Linear and nonlinear regression relationships between the survival (total and effective) of the boll weevil, type of overwintering habitat, temperature by type of habitat, diapause status, week of overwintered emergence, and other variables were computed using SHAZAM (White 1987). Coefficients of determination $\left(R^{2}\right)$, $t$ values of the parameters, and $F$ values were used to determine the significance of the regression models and the parameters.

Pheromone Trapping Studies. Another important aspect of the study was the placement of boll weevil pheromone traps in CRP grasses to determine the seasonal presence and movement of native weevils on the THP. Trapping studies were conducted during the period of October 1987 to July 1990 . During the first study year six traps were located in grass habitats located in Garza County within a $16-\mathrm{km}$ radius of the weeping lovegrass study site. The number of traps and trapping locations increased as the study progressed. With the addition of the native grass study site in September of 1988 , seven additional traps were placed in six CRP grass pastures located in Floyd and Motley counties. Beginning in early April 1989, the number of traps placed in CRP pastures increased to 35 traps located in 33 CRP fields. Numerous types of grasses in six counties were represented in the pheromone trap study. The fields were located from $8 \mathrm{~km}$ north of Dougherty (Floyd County) to $16 \mathrm{~km}$ southwest of Post (Garza County). Distance from the Caprock varied from $0.16 \mathrm{~km}(0.1 \mathrm{mile})$ to $8 \mathrm{~km}$ (4.5 miles), with an average distance of $3.2 \mathrm{~km}$ (2.0 miles).

Five additional traps placed in native grass habitats adjacent to the Caprock aided in the detection of boll weevil migration from the TRP onto the THP during the late summer and fall period. During the spring and early summer these traps were useful in detecting boll weevil emergence from overwintering habitats along the fringes of the Caprock. Four traps were located adjacent to the Stonewall County overwintering site, allowing a comparison of boll weevil activity in a predominantly sand shinnery oak habitat to that found on the THP.

Each Hercon Scout trap contained a 10-mg Hercon grandlure (McKibben et al. 1974) bait (2-wk rebaiting interval) and a toxicant strip containing propoxur. The traps were inspected weekly during the first 2 yr and every 2 wk during the third study year. Data from these traps indicated the presence and relative abundance of native weevils in the fields during the fall of the year. Weevils responding to these traps dur- 
Tuble 1. Numbers and diapouse status of boll weevils used in studies of the overwintering potential of boll weevils in two THP CRP grass hobitats and in sand shinnery oak leaf litler in the TRP, 1987-1990

\begin{tabular}{|c|c|c|c|c|c|}
\hline Period & $\begin{array}{l}\text { No. } \\
\text { cohorts }^{a t}\end{array}$ & $\begin{array}{c}\% \\
\text { Diapause, } \\
\bar{x} \pm \mathrm{SE}\end{array}$ & Habitat & $\begin{array}{l}\text { No. boll weevils } \\
\text { relensed }\end{array}$ & $\begin{array}{l}\text { No. } \\
\text { cages }\end{array}$ \\
\hline $1987-1988$ & $\begin{array}{l}5 \\
5\end{array}$ & $\begin{array}{l}89.8 \pm 8.9 \\
89.8 \pm 8.9\end{array}$ & $\begin{array}{l}\text { Weeping lovegrass } \\
\text { Sand shinnery onk lea l litter }\end{array}$ & $\begin{array}{l}2,768 \\
4,042\end{array}$ & $\begin{array}{l}10 \\
14\end{array}$ \\
\hline $1988-1989$ & $\begin{array}{l}8 \\
8 \\
8\end{array}$ & $\begin{array}{l}82.6 \pm 17.6 \\
82.6 \pm 17.6 \\
82.6 \pm 17.6\end{array}$ & $\begin{array}{l}\text { Weeping lovegrass } \\
\text { Native grass nixture }\end{array}$ & $\begin{array}{l}1,864 \\
1,864 \\
1,864\end{array}$ & $\begin{array}{l}15 \\
15 \\
15\end{array}$ \\
\hline $1989-1990$ & $\begin{array}{l}2 \\
2 \\
4\end{array}$ & $\begin{array}{l}85.0 \pm 5.0 \\
95.0 \pm 5.0 \\
84.3 \pm 14.8\end{array}$ & $\begin{array}{l}\text { Weeping lovegrass } \\
\text { Native grass mixture } \\
\text { Sand shinnery oak leaf litter }\end{array}$ & $\begin{array}{l}3,140 \\
3,140 \\
6,248\end{array}$ & $\begin{array}{r}8 \\
8 \\
16\end{array}$ \\
\hline
\end{tabular}

- Cohort release dates: 1987-1988: 12-16, 19-23, 26-30 Octuber; 2-6, 9-13 November; 1988-1989: 19-23, 26-30 September; 3-7, 17-21, 24-28 October; 3I October-4 November, 7-11, 14-18 November; 1989-1990: grass habitats: 18-22 September, 16-20 October; sand shinnery oak lea litter habitat: 11-15 September, 2-6, 9-13, 23-27 October.

ing the following spring and summer indicated possible overwintered boll weevil emergence from the CRP grasses.

\section{Results and Discussion}

Table I shows the number of boll weevil cohorts and individual boll weevils released into each type of habitat during the falls of 1987 , 1988 , and 1989. Almost 25,000 weevils were used in the studies.

Diapause Status. The results of dissections performed to determine the diapause status of boll weevils released into the selected habitats are shown in Table 1 . The percentage of diapausing boll weevils varied among cohorts but overall a large percentage of the released boll weevils were diapausing boll weevils as described by Brazzel \& Newsom (1959). Cohorts collected in the late summer typically had more reproductive boll weevils than cohorts collected in the fall. Although the sand shinnery oak leaf litter and grass habitat cohorts differed during the third year of the study, the overall percentage of diapausing boll weevils was slightly higher in the boll weevil cohorts released into the grass habitats (95 versus $84 \%$ ).

Habitat Temperature. Hourly readings from temperature probes inserted into the overwintering habitats were summarized in several different ways to illustrate differences in the insulating properties of the habitats. Comparisons of internal overwintering habitat temperatures (monthly means of the daily maximum and minimum temperatures) are presented in Figs. 2 and 3 . Because the study sites were separated geographically, mean monthly habitat-temperature values presented in Fig. 2 were calculated by determining habitat-temperature deviations from the corresponding local ambient air temperatures. A $y$-axis habitat-temperature value of zero equaled the ambient temperature for that particular study site. For each study year the selected time frame of November to July covered both the overwintering period and the spring-summer emergence period. Habitat-temperature data for weeping lovegrass are not presented for 19891990 because of an equipment failure in the datalogger for a 1 -mo period during the winter of 1989-1990.

The grass habitats were influenced to a greater extent by direct solar radiation than the sand shinnery oak leaf litter, which was shaded by the oak tree canopy. Fig. 2 shows that when compared with the local ambient temperature, the maximum daily temperatures in the grass habitats were frequently higher than in the shaded sand shinnery oak leaf litter.

For 1987-1988 and 1989-1990, Fig. 2 illustrates that during the winter and spring months, the minimum temperatures within the grass habitats were lower than in the sand shinnery oak leaf litter. During the summer months the mean minimum temperatures observed in the grasses tended to be slightly higher than the shaded shinnery oak habitat because of greater exposure to solar radiation during daylight hours.

A comparison of the maximum and minimum temperature graphs in Fig. 2 shows that daily temperature fuctuations were much greater in the grass habitats. During the winter months, grass habitats commonly had lower minimum daily temperatures and higher maximum temperatures than sand shinnery oak leaf litter. These fluctuations indicated that the insulating properties of the grass habitats were not as great as those of the shinnery oak leaf litter.

Fig. 3 shows the absolute temperatures $\left({ }^{\circ} \mathrm{C}\right)$ that the weevils actually experienced at the site of overwintering. The mean monthly maximum temperatures observed in the selected habitats did not differ greatly except that during the warmer months the grass habitat maximum means tended to be slightly highes when comparing monthly mean minimum temperatures, probably because of greater solar radiation exposure. Fig. 3 illustrates that when comparing monthly mean minimum temperatures, the sand shinnery oak leaf litter habitat consistently maintained a higher minimum mean temperature 


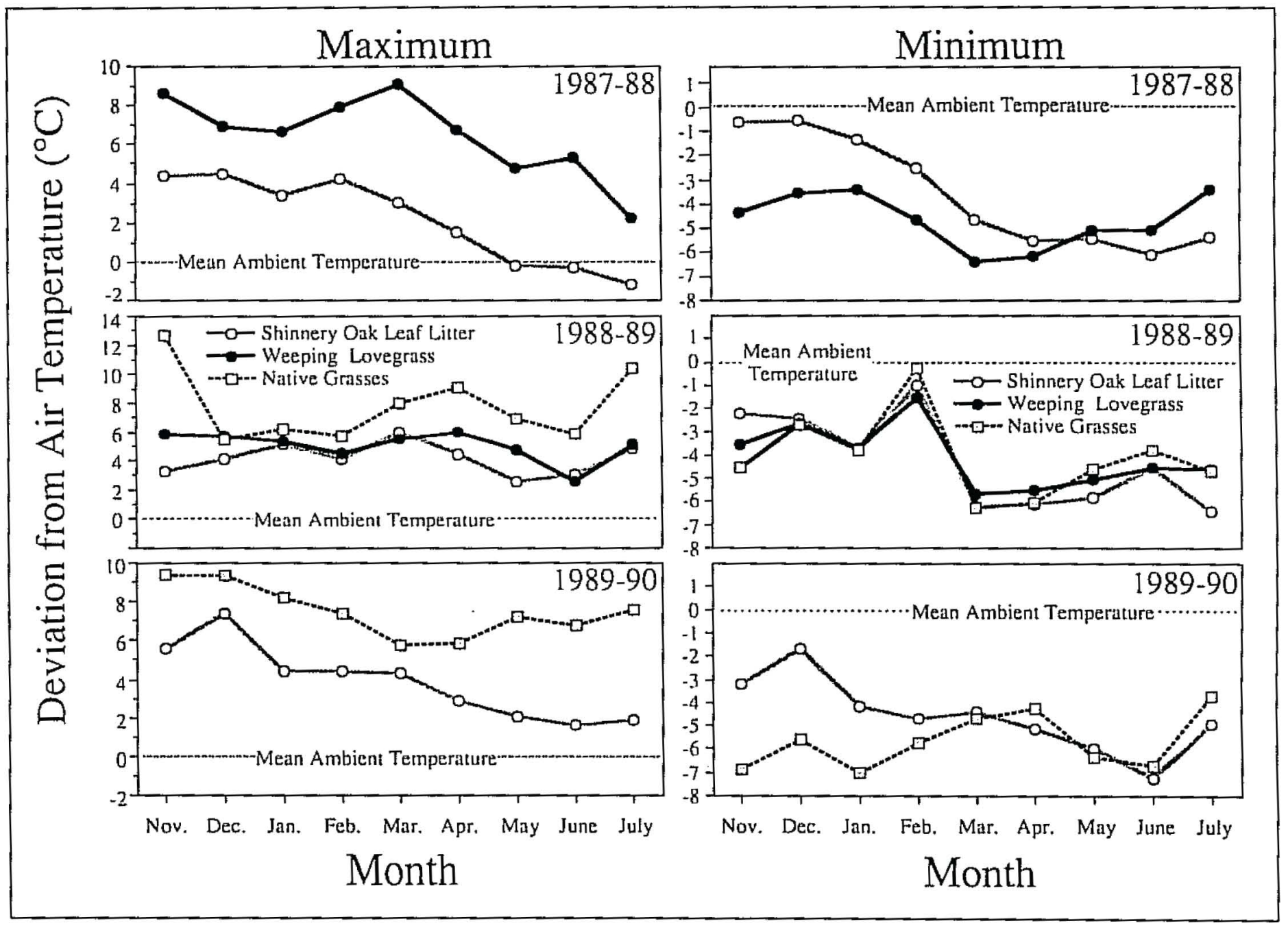

Fig. 2. Comparison of maximum and minimum temperatures obtained from temperature probes near the actual site of boll weevil overwintering in three habitats in Texas. The mean monthly values were calculated for deviations from the mean ambient air temperature at each study site, $1987-1990$. 


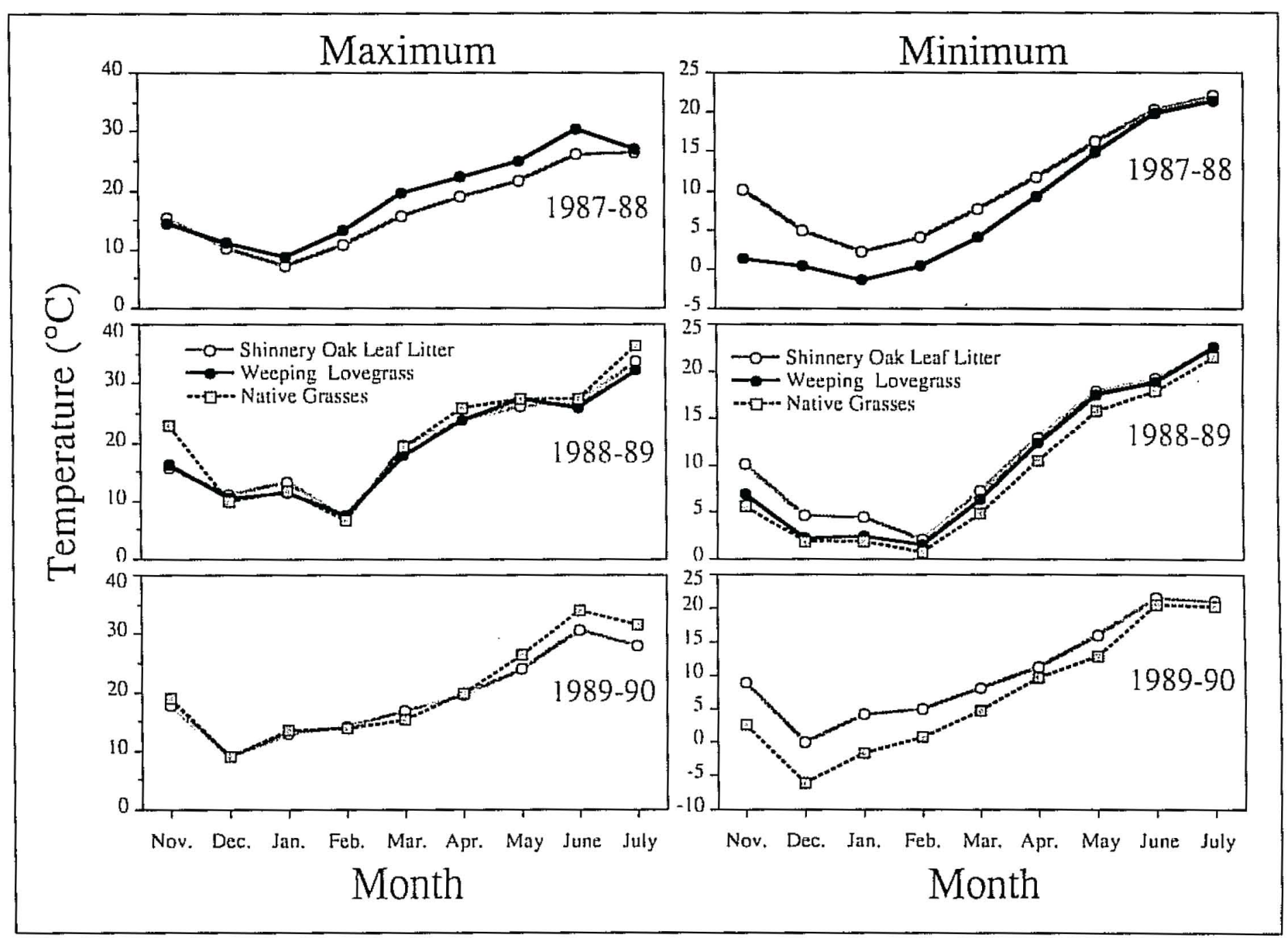

Fig. 3. Comparison of maximum and minimum absolute temperat ures ubtained from temperature probes near the actual site of boll weevil overwintering in three habitats in Texis, $1987-1090$. 
Table 2. Overwintered boll weevil emergence from three selected overwintering habilats in Texas, $1987-1990$

\begin{tabular}{|c|c|c|c|c|c|c|c|c|}
\hline \multirow{2}{*}{ Region } & \multirow{2}{*}{ County } & \multirow{2}{*}{ Habitat } & \multicolumn{6}{|c|}{$\mathrm{Yr}_{\mathrm{r}}$} \\
\hline & & & 1988 & 1989 & 1990 & 1988 & 1989 & 1990 \\
\hline & & & \multicolumn{3}{|c|}{$\%$ emergence ${ }^{0}$} & \multicolumn{3}{|c|}{ "to effective emergence ${ }^{a, b}$} \\
\hline $\begin{array}{l}\text { THP } \\
\text { THP } \\
\text { TRP }\end{array}$ & $\begin{array}{l}\text { Garza } \\
\text { Floyd } \\
\text { Stonewall }\end{array}$ & $\begin{array}{l}\text { Weeping lovegrass } \\
\text { Native grasses } \\
\text { Sand shinnery onk lear litter }\end{array}$ & $\begin{array}{l}1.3 \pm 0.9 \\
3.3 \pm 3.4\end{array}$ & $\begin{array}{l}0.5 \pm 0.6 \\
0.1 \pm 0.4 \\
3.1 \pm 2.2\end{array}$ & $\begin{array}{l}0.0 \pm 0.0 \\
0.0 \pm 0.0 \\
1.6 \pm 2.2\end{array}$ & $\begin{aligned} 0.4 \pm 0.5 \\
\pm .9 \pm 1.3\end{aligned}$ & $\begin{array}{l}0.0 \pm 0.0 \\
0.0 \pm 0.0 \\
0.3 \pm 0.8\end{array}$ & $\begin{array}{l}0.0 \pm 0.0 \\
0.0 \pm 0.0 \\
0.1 \pm 0.2\end{array}$ \\
\hline
\end{tabular}

${ }^{a} \bar{x} \pm S E$ based on $n=10$ and 14 for weeping lovegrnss and sand shinnery oak leaf litter, respectively in 1988; 15 in 1989; and 8,8 , and 16 for weeping lovegrass, native grasses, and sand shinnery oak lenf litter, respectively, in 1990.

Emergence after 15 June.

than the grass habitats during the winter months. Lower minimum temperatures in the grass habitats undoubtedly contributed to higher boll weevil overwintering mortality in the grass habitats as compared with the slightly warmer minimum temperatures in the sand shinnery oak leaf litter.

Total Percentage Emergence from Overwintering. Boll weevil winter survival in the different habitats is presented in Table 2. A severe Arctic storm during December 1989 resulted in a 1990 survival rate of $0 \%$ in both grass habitats. In the more protective sand shinnery oak leaf litter, $1.6 \%$ of the boll weevils survived the severe winter of 1989-1990. Overall, these survival data indicate that the insulating properties of the grass habitats were not adequate to allow substantial overwintering boll weevil survival during extremely cold weather. In addition, greater daily temperature fuctuations in the grass habitats were probably detrimental to boll weevil survival and likely influenced the timing of emergence (Slosser et al. 1984). Survival rates during the first 2 yr were considerably lower in the CRP grasses, but a small portion of the weevil population successfully overwintered in the THP grasses.

Temporal Patterns of Emergence. Numerous variables, such as winter severity and rainfall, influence the timing of emergence of boll weevils from overwintering habitat (Stone et al. 1990). For the purpose of this study, we have chosen to focus on how differences in habitat temperatures near the actual site of boll weevil overvintering influence the timing of overwintered emergence. The present study indicates that the effect of temperature on emergence timing and survival rates is great enough that other factors do not mask its influence.

The 1988 and 1989 cumulative emergence of boll weevils from weeping lovegrass and sand shinnery oak leaf litter is illustrated in Fig. 4. The 1988 cumulative emergence from lovegrass and sand shinnery oak habitats resulted in similar overall patterns. Emergence from both habitats started in March, and by mid-July almost $100 \%$ of the surviving boll weevils had emerged. For each type of habitat, the overall trends in the
1989 cumulative emergence were almost identical to those in 1988 .

The obvious difference in cumulative emergence from the different habitats occurred during the middle of the emergence period during both 1988 and 1989. From mid-April to early June, cumulative emergence from weeping lovegrass progressed faster than that observed from the sand shinnery oak leaf litter. Fenton \& Dunnam (1929) concluded that boll weevils wintering in habitats that offered minimum protection tended to have lower survival rates and accelerated emergence in the spring. Slosser et al. (1984) compared boll weevil survival and spring emergence in low-growing sand shinnery oak and in taller shinnery oak mottes of hybrid oaks that provided a dense canopy cover. They concluded that leaf litter in the more-open habitats received greater amounts of solar radiation, which resulted in higher temperatures and accelerated emergence of overwintered boll weevils in the spring. In the study reported here, the earlier emergence of overwintered boll weevils from grass habitats appears to be a result of this phenomenon. Earlier emergence from the grass habitats is advantageous from the cotton producers' standpoint because a smaller portion of the surviving boll weevils emerge late enough to be a threat to cotton. Although boll weevils tend to emerge earlier in the grass habitats than in the shinnery oak leaf litter habitat during the midApril to early-June period, the latter portion of the cumulative emergence curves was similar from both types of habitats. The 1989 emergence data from native grass habitat were omitted from Fig. 4 because of the extremely low survival $(0.1 \%)$. Likewise, the cumulative overwintered boll weevil emergence data of 1990 were omitted because of the $0 \%$ survival in both grass habitats.

Percentage Effective Emergence. In the study area, boll weevils that emerge after approximately 15 June have a much greater potential of living long enough to locate and colonize fruiting cotton than those emerging before 15 June (Rummel \& Carroll 1983). The late-emerging portion of the overwintered boll weevil population that presents the greatest threat to cotton production 


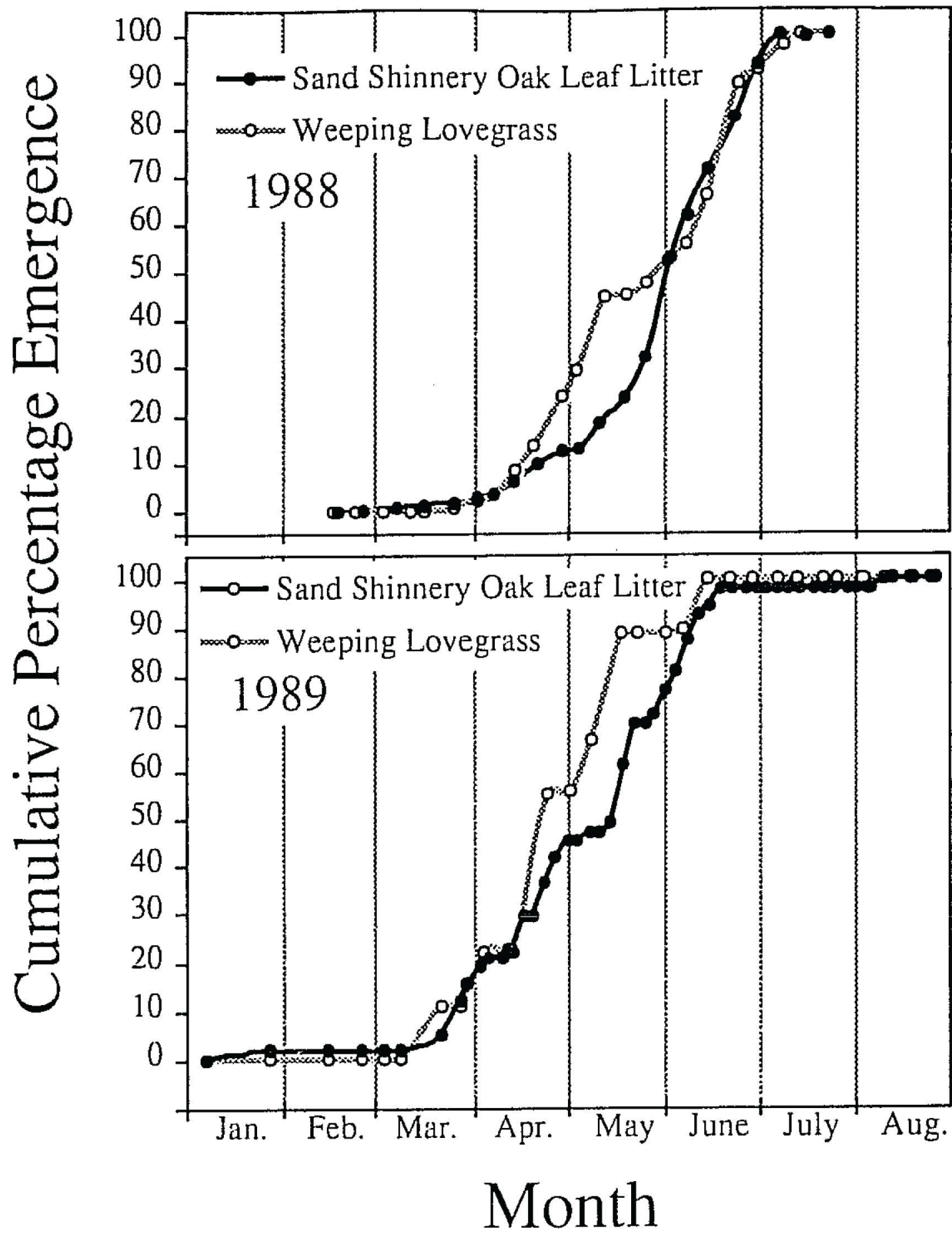

Fig. 4. Cumulative overwintered boll weevil emergence from weeping lovegrass (Garza County) and sand shinnery oak leaf litter (Stonewall County), 1988 and 1989.

is termed "effective emergence" (Fenton \& Dunnam 1927, Rummel \& Carroll 1983). The earlier portion of the emerging boll weevil population is referred to as "suicidal emergence" because most boll weevils in this group emerge too far in advance of fruiting to make a substantial contribution to reproduction. Table 2 shows the percentage effective emergence category. During all $3 y \mathrm{r}$ of the study, effective emergence rates were higher in the sand shinnery oak leaf 
litter than in the grass habitats. Because the grass habitat and sand shinnery oak habitat cumulative percentage emergence curves were similar during the effective emergence period (Fig. 4), the higher effective emergence rates observed in the sand shinnery oak habitat were due primarily to overall higher rates of survival in the sand shinnery oak leaf litter. The only effective emergence observed in the grass habitats was from the weeping lovegrass during 1988, but effective emergence occurred during all $3 \mathrm{yr}$ from the sand shinnery oak leaf litter habitat.

Pheromone Trap Catches. Beginning in August, boll weevils captured in traps in CRP grass pastures along the Caprock reflected boll weevil migration from the TRP to the THP (Bottrell et al. 1970). Migration of boll weevils from the TRP to the THP accounted for most of the boll weevil response to traps during August and September (Fig. 5). During the period of mid-September to December, the THP trap response curve normally represented continued migration and local reproduction. Boll weevil response to traps usually ended several weeks after the first plantkilling freeze, which generally occurred during late October or early November. From early August to mid-December of 1988 and 1989, the total number of boll weevils captured per THP trap was $26.0 \pm 11.6$ and $268.5 \pm 179.8$, respectively. Traps located near the sand shinnery oak leaf litter overwintering site in the TRP captured much larger cumulative trap captures of $6,126 \pm$ 1,009 and $2,693 \pm 328$ during the falls of 1988 and 1989 , respectively.

In the study area, boll weevils captured in pheromone traps from mid-February to mid-July were typically overwintered weevils that had recently emerged from nearby overwintering habitat (Carroll \& Rummel 1985). Boll weevils captured in pheromone traps located in or adjacent to CRP pastures on the THP indicated a low level of overwintered boll weevil emergence during all $3 \mathrm{yr}$ of the study (Fig. 5). The cumulative number of boll weevils captured per trap during the overwintered boll weevil emergence period of 1988,1989 , and 1990 was $0.5 \pm 0.5$, $4.5 \pm 6.8$, and $0.1 \pm 0.3$, respectively. In comparison, cumulative captures in traps placed near the TRP sand shinnery oak study site were 2,745 $\pm 372,5,203 \pm 683$, and $112 \pm 23$ for 1988,1989 , and 1990 , respectively.

Most of the boll weevils captured in THP traps were probably from small populations that overwintered on the THP. Some of these boll weevils probably emerged from CRP pastures near the traps, but others may have emerged from other nearby overwintering habitats such as vegetation around abandoned farmsteads and bushy areas along the Caprock.

As a result of the low temperatures of December 1989 , native boll weevil activity on the THP was very limited during 1990 . Although boll weevil populations were relatively large during the fall of 1989 (Fig. 5), only three boll weevils were captured in 35 THP traps during the spring and summer emergence period of 1990 . Evidently, native boll weevils attempting to overwinter in available habitats on the THP suffered the same fate as caged test boll weevils in the grasses.

Relationship of Emergence to Temperature. In terms of explaining the total emergence and effective emergence of the boll weevil across overwintering habitat type, a linear first-order equation utilizing negative degree-day (NDD) accumulations in the longest run of days with temperatures below $-3.9^{\circ} \mathrm{C}$ (Stone et al. 1990) proved to be the most statistically appropriate. This temperature-related variable, which is a function of both minimum temperature and time, served as the independent variable in the regression models.

Table 3 presents regression estimates for both percentage total overwintered boll weevi] emergence and effective emergence by type of overwintering habitat. A regression for effective emergence from the native grass habitat was not estimated because effective emergence of boll weevils from native grass habitat was zero in both study years, and there was no variability to be explained. As expected, because of the crosssectional nature of the data used in this analysis, low coefficients of determination $\left(R^{2}\right)$ occurred because of the within-year variation across overwintering habitats (Pindyck \& Rubinfeld 1981). However, as pointed out in Table 3 , in three of the five regression models estimated, the null hypothesis that the NDD variable does not explain the variation of survival (total and effective) is rejected (the $F$ statistic is significant at the $5 \%$ level). Also, it is important to point out that the signs of the estimated parameters were as expected, and of the parameters estimated, seven were significant at the $1 \%$ level. In particular, it should be noted that in the three models in which the $F$ statistic is significant at the $5 \%$ level, the parameters estimated are significant at the $1 \%$ level.

The Chow test (Chow 1960) revealed that the null hypothesis (that the regressions are statistically the same across habitats [sand shinnery oak leaf litter, weeping lovegrass, and native grasses]) for total emergence was rejected at the $1 \%$ level. However, for effective emergence, the null hypothesis that the regressions are statistically the same across habitats (sand shinnery oak leaf litter and weeping lovegrass) was not rejected. That is, for total emergence, separate regressions for each habitat must be estimated, but for effective emergence, estimation of separate regressions for each habitat is not necessary.

The regression results in Table 3 indicate that when the NDD variable is zero, reflecting mild temperatures favorable for boll weevil winter 

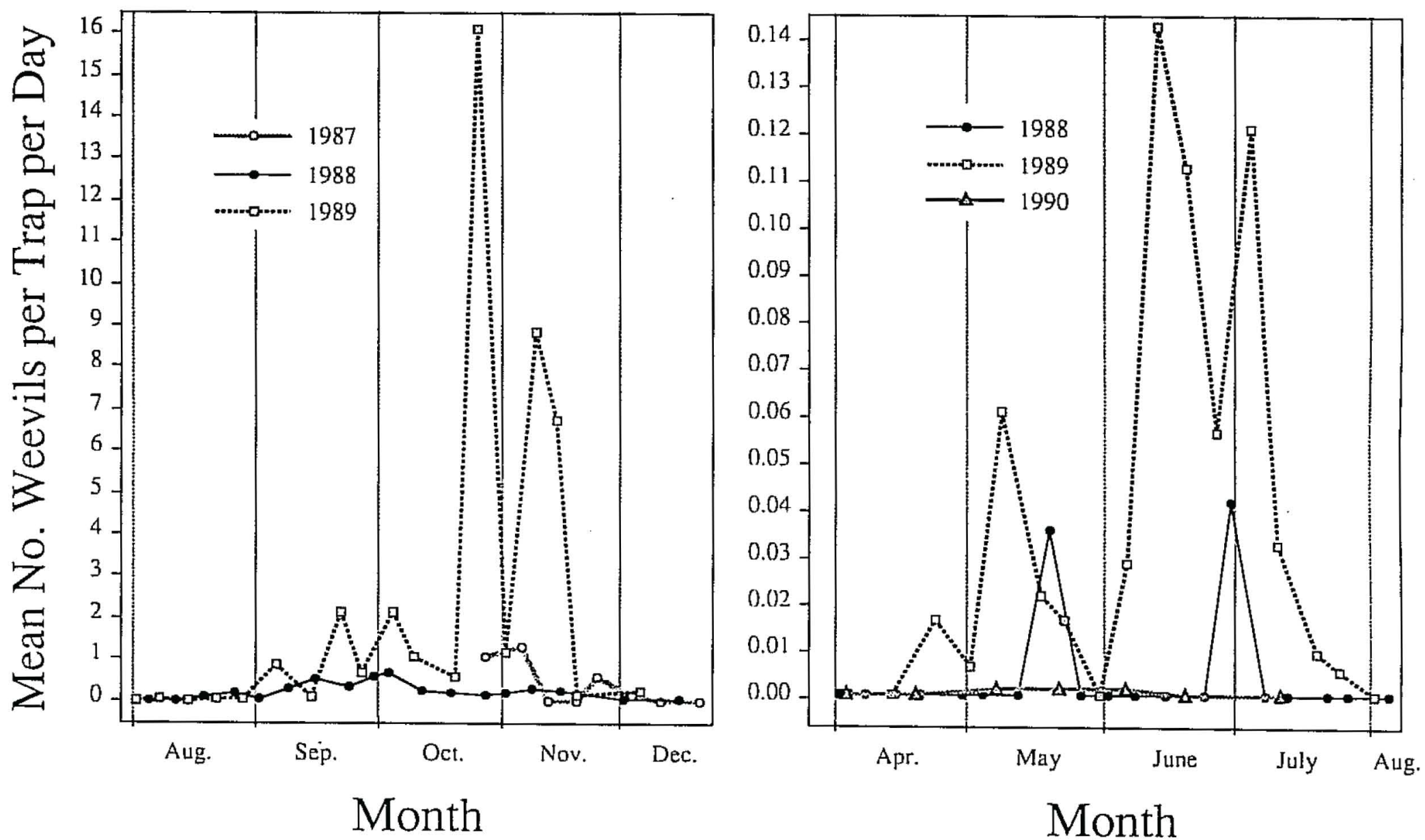

Fig. 5. Catches of native boll weevils in pheromone traps placed in CRP pastures located on the THP, 1987-1990. 
Table 3. Regression results for emergence of boll weevils caged on three selected overwintering habitats in Texns as a function of NDD accumulations, I 987-1990

\begin{tabular}{|c|c|c|c|c|c|c|c|}
\hline \multirow[b]{2}{*}{$\begin{array}{l}\text { Dependent variable } \\
(Y)^{\mathrm{a}}\end{array}$} & \multirow[b]{2}{*}{ Habitatb } & \multirow[b]{2}{*}{$n$} & \multicolumn{2}{|c|}{ Parameter } & \multirow[b]{2}{*}{$R^{2}$} & \multirow[b]{2}{*}{$p^{\prime \prime}$} & \multirow[b]{2}{*}{$F^{e}$} \\
\hline & & & $\begin{array}{c}\text { Intercept }\left(b_{0}\right) \\
\mathrm{E} \pm \mathrm{SEE}\end{array}$ & $\begin{array}{c}\text { Slope }\left(b_{1}\right) \\
E \pm \text { SEE }\end{array}$ & & & \\
\hline \multirow[t]{3}{*}{ \% total emergence } & Weeping lovegrass & 33 & $1.3605 \pm 0.2232$ & $-0.0286 \pm 0.0074$ & 0.3255 & 0.0009 & $14.961^{*}$ \\
\hline & Native grasses & 23 & $0.5620 \pm 0.6876$ & $-0.0110=0.0153$ & 0.0242 & 0.4632 & 0.522 \\
\hline & Sand shinnery oak leaf litter & 45 & $3.7677 \pm 0.7223$ & $-0.0515 \pm 0.0287$ & 0.0698 & 0.0932 & 3.226 \\
\hline \multirow[t]{2}{*}{ To effective emergence } & Weeping lovegrass & 33 & $0.3504=0.0969$ & $-0.0086 \pm 0.0032$ & 0.1899 & 0.0100 & $7.265 *$ \\
\hline & Sand shinnery oak leaf litter & 45 & $0.9477 \pm 0.2346$ & $-0.0244=0.0093$ & 0.1380 & 0.0097 & $6.887^{\circ}$ \\
\hline
\end{tabular}

a Pegression model $Y=b_{0}+b_{1} x$ fit to emergence data using SHAZAM (White 1987).

b No regression for percentage effective emergence on native grasses because of lack of variation.

- Parameter estimate \pm standard error of the estimate.

¿ Test of $\mathrm{H}_{0}: \mathrm{b}_{1}=0$ using $t$ test.

- *Significant at the $5 \%$ level.

survival, the upper limits of total boll weevil survival will be $3.77,1.36$, and $0.56 \%$ in shinnery oak leaf litter, weeping lovegrass, and native grass habitats, respectively. This indicates that in relative terms, total survival in the sand shinnery oak habitat would be $\approx 2.5$ times that expected in the weeping lovegrass habitat. Likewise, total survival in the sand shinnery oak habitat would be $=6.5$ times the survival rate observed in the native grasses. The magnitude of the differences in the survival rates between the different types of habitats would tend to be large during mild winters but quite small during severe winters Jike that of 1989-1990.

It is important to note that for total survival the impact of the NDD variable had a greater impact on boll weevil mortality in sand shinnery oak habitat $(-0.0515)$ than in the lovegrass habitat $(-0.0286)$. Likewise, the NDD variable has a greater impact on boll weevil mortality in the weeping lovegrass habitat $(-0.0286)$ than in the native grasses habitat $(-0.0110)$. Regarding effective emergence of boll weevils, the relationships for both sand shinnery oak and weeping lovegrass were similar to those for total survival. However, the magnitude of all parameter estimates was reduced.

The results of this study show that CRP grasses in the THP provide rather marginal winter habitat for the boll weevil when compared with sand shinnery oak litter, the prime overwintering habitat in the adjacent TRP area. However, pheromone trap records indicate that small numbers of native boll weevils did survive the winter in CRP grasses during some years of the study. Therefore, if large enough diapausing boll weevil populations develop in the fall, even low winter survival rates in the CRP grasses could result in damaging boll weevil infestations in THP cotton.

\section{Acknowledgments}

We would like to thank our cooperators, J. T. Murdoch, H. Vance Campbell, and the Thuett family, who generously allowed us access to their agricultural lands. We also appreciate the assistance of M. A. Arnold (Texas Agricultural Experiment Station, Lubbock, TX) in maintaining and manipulating the computerized weather data utilized in this study, and J. E. Slosser (Texas Agricultural Experiment Station, Vernon, TX) and T. W. Fuchs (Texas Agricultural Extension Service, San Angelo, TX) for critical reviews of the manuscript. This study was conducted under Texas Agricultural Experiment Station Project H-6991 and was funded in part by Plains Cotton Growers, Inc., Boll Weevil Steering Committee. The manuscript was approved for publication by the Director of the Texas Agricultural Experiment Station, Texas A\&M University System, as Technical Article No. 30546.

\section{References Cited}

Adkisson, P. L., J. W. Davis, W. L. Owen \& D. R. Rummel. 1965. Evaluation of the 1964 diapause boll weevil control program on the High Plains of Texas. Texas A\&MI University, Department of Entomology Technical Report No. 1. College Station, TX.

Bottrell, D. G., R. E. Reeves, L. K. Almond, D. D. Hardee \& W. H. Cross. 1970. Studies of boll weevil populations and their movements in the High and Rolling Plains of Texas using maJe-baited traps, 1968. Misc. Pub.-948. Tex. Agric. Exp. Stn., Texas A\&M University, College Station, TX. 8 pp.

Bottrell, D. G., D. R. Rummel \& P. L. Adkisson. 1972a. Spread of the boll weevil into the High Plains of Texas. Environ. Entomol. 1: 136-140.

Bottrell, D. G., J. R. White, D. S. Moody \& D. D. Hardee. 1972b. Ovenwintering hahitats of the boll weevil in the Rolling Plains of Texas. Environ. Entomol. 1: 633-638.

Brazzel, J. R. \& L. D. Newsom. 1959. Diapause in Anthonomus grondis Boheman. J. Econ. Entomol. 52: 603-611.

Brown, C. M. \& S. A. Phillips. 1989. Weeping lovegrass as an overvintering habitat for the boll weevil (Coleoptera: Curculionidae). J. Econ. Entomol. 82: $799-802$.

Carroll, S. C. \& D. R. Rummel. 1985. Relationship between time of boll weevil (Coleoptera: Curculionidae) emergence from winter habitat and response to grandlure-baited pheromone traps. Environ. Entamol. 14: 447-451.

Chow, G. C. 1960. Test of equality between sets of 
coefficients in two linear regressions. Econometricn 28: 591-605.

Fenton, F. A. \& E. W. Dunnam. 1927. Winter survival of the cotton boll weevil at Florence, South Carolina. J. Econ. Entomol. 20: 327-336.

1929. Biology of the cotton boll weevil at Florence, South Carolina. U.S. Dep. Agric. Tech. Bull. 112.

Gould, F. W. 1962. Texas plants, a checklist and ecological summary. Misc. Pub.-585. Tex. Agric. Exp. Stn., Texns A\&M University, College Station, TX.

McKibben, G. H., T. B. Davich, R. C. Gueldner, D. D. Hardee \& P. A. Hedin. 1974. Polymeric composition for attracting boll weevils. U.S. Pat. No. $3,803,303$.

Pindyck, R. S. \& D. L. Rubinfeld. 1981. Econometric models and economic forecasts, 2nd ed. McGraw-Hill, New York.

Rummel, D. R. \& P. L. Adkisson. 1970. Distribution of boll weevil-infested colton fields in relation to overwintering habitats in the High and Rolling Plains of Texas. J. Econ. Entomol. 63: 1906-1909.

Rummel, D. R. \& S. C. Carroll. 1983. Winter sur- vival and effective emergence of boll weevil cohorts entering winter habitat at different times. Southwest. Entomol. 8: 101-106.

Rummel, D. R., D. G. BottrelI, P. L. Adkisson \& R. C. McIntyre. 1975. An appraisal of a 10-year effort to prevent the westward spread of the boll weevil. Bull. Entomol. Soc. Am. 21: 6-11.

Slosser, J. E., J. R. Price \& P. W. Jacoby. 1984. Effect of two shinnery oak habitats on winter survival and early summer emergence of the boll weevil. Southwest. Entomal. 9: 240-244.

Stone, N. D., D. R. Rummel, S. Carroll, M. E. Makela \& R. E. Frisbie. 1990. Simulation of boll weevi] (Coleoptera: Curculionidea) spring emergence and overwintering survival in the Texas Rolling Plains. Environ. Entomol. 19: 91-98.

White, K. J. 1987. SHAZAM: a general computer program for econometric methods (version 5). Am. Stat. $41: 80$.

Received for publication 24 February 1992; accepted 19 October 1992. 